\title{
DISPLAYED DEXTERITY AND DISTORTED KNOWLEDGE: AMATEURISM AND PRECISION IN LATE 18TH CENTURY SPAIN
}

\author{
Nuria Valverde \\ Universidad Autónoma Metropolitana, México DF
}

\begin{abstract}
This paper explores the links between scientific practice and precision both in expert networks and popular literature in the second half 18th century Spain. It will be argued that scientific instruments were used and understood in different ways in these two networks, which required opposing strategies for visualizing the degree and goodness of users' dexterities, thereby fostering the emergence of different collective and individual (epistemic) subjects. I will also argue that these subjects' differences and affinities were constructed around three themes: firstly, the degree of precision needed to establish a correlation between data and the world, or, in other words, the degree of fluidity admitted in connecting material and cultural worlds; secondly, the relevance attributed to body and bod(il)y knowledge in producing reliable data and stabilizing expertise; and thirdly, the weight attributed to opinion in leaning towards ephemeral or lasting data. The first part of the paper looks at the epistemological and political confluences which in late 18th century Spain nurtured the emergence of both a culture of precision and a sphere of public opinion, and to the strained relationship that existed between them. The other three sections explore how Spanish people used different sets of practices to construct different images of themselves as supporters of a moral of precision.
\end{abstract}

KEY WORDS: Precision. Enlightenment. Amateurism. Body knowledge. Spain. Epistemic cultures.

\section{DESTREZA DEMOSTRADA Y CONOCIMIENTO DISTORSIONADO: LO AMATEUR Y LA PRECISIÓN EN LA ESPAÑA DE FINALES DEL SIGLO XVIII \\ RESUMEN}

En este artículo se analiza la relación entre el ejercicio científico y la precisión científica tanto en las redes de expertos como en la literatura popular en la España de la segunda mitad del siglo XVIII. Se mostrará que los instrumentos científicos fueron utilizados y comprendidos de diferentes maneras en estas dos redes, lo cual requirió aplicar unas estrategias opuestas para visualizar el grado y la eficacia de las destrezas de los usuarios, y por lo tanto impulsó la emergencia de diferentes sujetos colectivos e individuales (epistémicos). También demostraré cómo estas diferencias y afinidades de sujetos se construyeron alrededor de tres temas: en primer lugar, el grado de precisión necesario para establecer una correlación entre los datos y el mundo o, en otras palabras, el grado 
de fluidez admitido para conectar el mundo material y el mundo cultural; en segundo lugar, la importancia atribuida al cuerpo y al conocimiento del cuerpo para producir datos fiables y establecer la experiencia; y en tercer lugar, el peso atribuido a la opinión al respaldarse en datos efímeros o duraderos. La primera parte del artículo se centra en las confluencias epistemológicas y políticas que en la España de finales del siglo XVIII impulsaron la emergencia tanto de una cultura de precisión como de una esfera de opinión pública, y de la tensa relación que existía entre ambas. Los otros tres apartados analizan cómo los españoles utilizaron diferentes conjuntos de prácticas para construir diferentes imágenes de ellos mismos como defensores de una moral de la precisión.

PALABRAS CLAVE: Precisión. Iluminación. Amateur. Conocimiento del cuerpo. España. Precisión. Culturas epistémicas.

[Los fenómenos celestes] llenarían de pavor al Astrónomo, si no se sucediesen en el momento indicado por el cálculo

[Celestial phenomena] would fill the Astronomer with dread if they did not happen at the moment indicated by calculations

Gilleman, 1761: 2v

In the autumn of 1788, a rather surprising news item was published in the fortnightly journal Correo de Madrid by order of the Council of Castile, equivalent to the present Ministry of the Interior:

The Council having held an inquiry into Don Pedro Alonso de Salanoba, author of a slanderous paper on Astronomy published on January 10th of this year, it turned out to be full of astronomic errors and mistakes - as reported by experts in this science - and thus last June 26th it was agreed to forbid its reprinting, either separately or inserted [in another work]; and also [it was agreed] that any work on Astronomy or related topics be submitted to Colonel Mr. Antonio Gilleman's censorship, due to the great satisfaction the Council has with him [The Council] has ordered this notice to be published in order to make amends to the interested person, and to prevent the same errors in astronomic affairs from being committed henceforth. ${ }^{1}$

It is unclear which paper the news was referring to; but the inquiry came along after a public controversy between the above mentioned Gilleman and the journalist Salanova. Anyway, this intervention by the State highlights the close political connections between public instruction, the sphere of public

1 Anónimo (1788), Correo de Madrid, November 15, 207, p. 1282. 
opinion and the spread of a moral economy of precision which the Spanish government had been promoting since the 1740s. As vehicles of values and practices that helped to stabilize a new social order, scientific instruments played a major role in the government's task. At the same time, discussions between experts and non-experts on the legitimate use of instruments and the accuracy of the results which they provided pointed to the limitations of technologies in producing the same epistemic communities. One of the problems seems to have been rooted in the difficulties of assessing the observer's role in attaining an expected degree of accuracy. At a moment of technological openness, when scientific instruments were not completely interchangeable and their function was still being settled, the point at which the observer's activity should be visualized for reasons of control or reliability was a controversial question. It could make a great difference in the way precision and accuracy was defined, and has important technological and social consequences.

The aim of this paper is to explore how scientific practice was understood both in expert networks and popular literature, focusing on the ways in which different actors used instruments and how they made distinctions between good and/or suitable practices and those that were not. It will be argued that scientific instruments were used and understood in different ways in these two networks, which required opposing strategies for visualizing the degree and goodness of users' dexterities, thereby fostering the emergence of different collective and individual (epistemic) subjects. I will also argue that these subjects' differences and affinities were constructed around three themes: firstly, the degree of precision needed to establish a correlation between data and the world, or, in other words, the degree of fluidity admitted in connecting material and cultural worlds; secondly, the relevance attributed to body and bod(il)y knowledge in producing reliable data and stabilizing expertise; and thirdly, the weight attributed to opinion in leaning towards ephemeral or lasting data.

The first part of the paper looks at the epistemological and political confluences which in late 18th century Spain nurtured the emergence of both a culture of precision and a sphere of public opinion, and to the strained relationship that existed between them. The other three sections explore how Spanish people used different sets of practices in order to construct different images of themselves as supporters of a morals of precision: as observers that developed their work in the field and in the observatories within formal networks, as readers, or as independent practitioners that found new spaces for promoting the use of scientific instruments. 


\section{DEXTERITIES AND PRECISION NETWORKS}

During the second quarter of the 18th century, the fight against «vulgar errors» and superstition took on a new dimension in Spain. In 1726 the first volume of the Benedictine Benito Jerónimo Feijóo y Montenegro's (16761764) most famous work, Teatro crítico universal (Discursos varios en todo género de materias, para desengaño de errores comunes), became a surprise best seller. ${ }^{2}$ Feijóo, whose cultural influence reached every social stratum, stressed in his works the importance of the figure of the impartial critic, who had the emotional distance needed for equanimity. Forged to a great extent in order to justify the task of newspapers, this figure was to transform the negative view of the role of judges, generally seen by the Republic of Letters as presumptuous and tyrannical. ${ }^{3}$

A substantial change in the social value of equanimity occurred at the end of the century when, with the suspicions awakened by the French Revolution still fresh in many minds, José Isidoro Morales (1758-1818), a professor at the Colegio de Caballeros Pages del Rey, wrote his Memoria matemática (1797). The work dealt with the mathematical method for the election of candidates «by order of merit» first proposed by the French mathematician JeanCharles Borda (1733-1799) in 1770. In Morales' view, opinion was no more than «an illusion of majority when it is only counted and not weighted;» ${ }^{4}$ and his work:

applies calculus to show how far current methods are from truth and accuracy, (which in these affairs are the same as justice) and employs analysis to demonstrate the rigour and accuracy of the method $[\ldots] .5$

Equanimity, the attribute of the wise person, was now placed in mathematical contrivance. We are faced here with a new sensibility, summarised by

2 The nine volumes of the Teatro critico, together with the five of the Cartas eruditas, and the two carrying replies to Mañer and Soto Marne, went through 90 editions in Feijóo's lifetime.

3 Goldgar, A. (1995), Impolite Learning. Conduct and Community in the Republic of Letters, 1680-1750, London/New Haven, Yale University Press, pp. 111-114.

4 Morales, J.I. (1797), Memoria matemática sobre el cálculo de la opinión en las elecciones, Madrid, Imprenta Real (Facsimile ed. in LARA RóDENAS, M.J. (ed.) (2001), José Isidoro Morales, un matemático en la corte de Carlos $I V$, Huelva, Universidad de Huelva), p. 8.

5 Morales, J.I. (1797), Prólogo, s/n. 
Morales in a single sentence: «to approach accuracy, i.e. justice.» ${ }^{6}$ In accordance with the quantifying spirit of the times, this close, almost intimate link between accuracy and justice was built on analogies with precision instruments, posing interesting questions such as whether it were morally acceptable to put into non-expert hands the making and surveillance of the scale of a balance.

The all-pervasive heuristic value of balances, as shown by N. Wise, ${ }^{7}$ eased the transit from physics to economics, from mathematical to political authority. It was by claiming a deep understanding of mechanical models that engineers opened the doors to a selective mechanization of the subject and, hence, to social design. ${ }^{8}$ Morales' concern about the morality of entrusting nonexperts with responsibilities demanding highly skilled knowledge was also the consequence of a political context where greater authority on the part of scientists and engineers seemed to be required to implement successful technological mobilization and economic production. However, it also reflects the now problematical role of training, a subjective basis of knowledge upon which the shareability of knowledge and epistemic values had once been constructed, in the new understanding of expert knowledge as a different sphere with great potential for structural change. The emergence of objectivity as a major value in the solution of political disputes, achieved through a set of well-established practices and technologies, was related to a process of appropriation of common knowledge - or extelligence, to use Stewart and Cohen's term -9 and a redefinition of body knowledge according to the new observational practices then enforced.

The political roots of precision in Spain are strong and visible. Firstly, in the extent and increase of accountability, mostly related to the implementa-

6 Morales, J.I. (1805), Apéndice a la Memoria Matemática sobre el cálculo de la opinión en las elecciones, Madrid, Imprenta de Sancha (Facsimilar ed. in LARA RóDENAS, M.J. (ed.) (2001), José Isidoro Morales, un matemático en la corte de Carlos IV, Huelva, Universidad de Huelva), p. 17.

7 Wise, N. (1993), Mediations: Enlightenment Balancing Acts, or the Technologies of Rationalism. In Horwich, P. (ed.), World Changes. Thomas Kuhn and the Nature of Science, Cambridge-Ma./ London, MIT press, pp. 207-256.

8 SChaffer, S. (1999), Enlightened Automata. In Clark, N., Golinski, J. and Schaffer, S. (eds.), The Sciences in the Enlightened Europe, Chicago, University of Chicago Press, pp. 126-167.

9 Stewhrt, I. and Cohen, J. (1999), Figments of Reality. The Evolution of the Curious Mind, Cambridge, Cambridge University Press, p. 243. 
tion of cadastral works from 1749 to $1756 ;{ }^{10}$ secondly, in the impressive expeditionary enterprises undertaken from 1750 on; and thirdly, in the emergence of biopolitics ${ }^{11}$ and increasing disciplinary control of the kind of training deemed necessary to carry out a trade (a main part of the productive value of the population),,$^{12}$ as implemented through political measures such as those proposed by the finance minister Pedro Rodríguez de Campomanes (17231802)..$^{13}$ All three developments manifest not only the perceived need for

10 For a detailed account of the nature and development of these works see CAMARERO BulLón, C. (2002), Vasallos y pueblos castellanos ante una averiguación más allá de lo fiscal: el Catastro de Ensenada, 1749-1756. In El Catastro de Ensenada: magna averiguación fiscal para alivio de los Vasallos y mejor conocimiento de los Reinos, 1749-1756, Madrid, Ministerio de Hacienda-Dirección General del Catastro, pp. 113-387.

11 Foucault, M. (1978), La gouvernementalité. In (2001), Dits et écrits II, 1976-1988, Paris, Gallimard, pp. 635-657; FouCAUlt, M. (1981), Les mailles du pouvoir. In (2001), Dits et écrits II, 1976-1988, Paris, Gallimard, pp. 1001-1020; PORTER, T. (1995), Trust in Numbers. The Pursuit of Objectivity in Science and Public Life, Princeton, Princeton University Press, pp. 50ff.; HACKING, I. (1995), La domesticación del azar. La erosión del determinismo $y$ el nacimiento de las ciencias del caos, Barcelona, Gedisa, has explored in depth the connections between the development of calculus and the emergence of biopolitics.

12 «Human capital», understood in the modern sense of the technical training, education and health services provided to civilians in order to improve the quality of production, was an increasingly widespread notion throughout the century, mainly in the work of Melchor Gaspar de Jovellanos (1744-1811) (See FuENTES QuintanA, E. (2000), Una aproximación al pensamiento económico de Jovellanos a través de las funciones del Estado. In FUENTES QUINTANA, E. (dir.), Economía y economistas españoles, Vol. 3. La Ilustración, Barcelona, FCAC/Galaxia Gutenberg-Círculo de Lectores, pp. 331-420. The economic weight of technoscientific knowledge fostered, as in other European countries, the understanding of it as a common good whose sharing and evaluation was a primary strategy for the advancement of the country. This clearly affected the secrecy surrounding the guilds' system of transmission of knowledge as well as the way authority was understood. See THAMER, H.U. (1984), On the Use and Abuse of Handicraft: Journeyman Culture and Enlightened Public Opinion in 18th and 19th Century Germany. In Steven Kaplan, L. (ed.), Understanding Popular Culture. Europe from the Middle Ages to the Nineteenth Century, Berlin/New York/Amsterdam, Mouton, pp. 275-300; Hilaire-PÉREZ, L. (2002), Diderot's views on artists' and inventors' right: invention, imitation and reputation, British Journal for the History of Science, 35 (2), pp. 129 150; Hilaire-PÉreZ, L. (1991), Invention and the State in 18th-Century France, Technology and Culture, 32 (4), pp. 911-931; HABERMAS, J. (1994), The Structural Transformation of the Public Sphere. An Inquiry into a Category of Bourgeois Society, Cambridge, MIT Press, p. 54.

13 Campomanes was greatly influenced by physiocracy and argued for sweeping reform of the guilds and the creation of new channels of information (such as Patriotic or Economic Societies) through which the «natural mediators» of the rural world -i.e. the provincial nobility and clergy - would be able to bridge the gap between the highly centralized and theoreti- 
better control over economic resources, but an increasing dependence of domestic politics on an international framework, based on the new tools and values emanating from scientific culture.

Directly or indirectly, the English economic revolution, linking commerce to virtue and knowledge to the symbolic mobilization of properties, ${ }^{14}$ spurred the search for reliable and abundant information on the geography and natural wealth of the American colonies. Simultaneously, the end of the culture of wonders redefined the nature of trustworthy information by imposing in the Republic of Letters new rules aimed to control its contents, ${ }^{15}$ enabling an economic approach to the riches of Nature. ${ }^{16}$ The new Republic that emerged

cal projects of the Academies and their implementation. Campomanes' ideas spread quickly and strongly: 30,000 copies of his Discurso sobre el fomento de la industria popular (1774) were sent in the year of its publication to various religious and official institutions. The measure seems to have been reasonably successful, given that 60 patriotic societies were created between 1774 and 1785. CASTRO, C. DE (1996), Campomanes. Estado y reformismo ilustrado, Madrid, Alianza Editorial, p. 184; Llombart RosA, V. and AstigARrAGA GoenAGA, J. (2000), Las primeras antorchas de la economía: las sociedades económicas de amigos del país en el siglo XVIII. In FuENTES QUINTANA, E. (dir.), Economía y economistas españoles. Vol. 3. La Ilustración, Barcelona, FCAC/Galaxia Gutenberg-Círculo de Lectores, pp. 680, 689, 690; Llombart Rosa, V. (2000), Campomanes, el economista de Carlos III. In FUENTES Quintana, E. (dir.) Economía y economistas españoles. Vol. 3. La Ilustración, Barcelona, FCAC/Galaxia Gutenberg-Círculo de Lectores, pp. 227-236.

14 Pocock, J.G.A. (1975), The Machiavellian Moment. Florentine Political Thought and the Atlantic Republican Tradition, Princeton, Princeton University Press, p. 442.

15 The crisis of the cultures of wonder has been analysed from an epistemological viewpoint by Daston and Park (DASTON, L. and PARK, K. (2001), Wonders and the Order of Nature, 1150-1750, New York, Zone Books, chap. 9). Gorman has explored how the credibility of Jesuit science was affected by this process (GoRMAN, M.J. (1999), From the «Eyes of All» to «Useful Quarries in philosophy and good literature:» Consuming Jesuit Science 1600-1665. In O'MALley, J.W. et al. (eds.), The Jesuits. Cultures, Sciences, and the Arts, 1540-1773, Toronto/Buffalo/London, University of Toronto Press, pp. 170-189). For the attention paid to contents mostly after 1720, see DASTON, L. (1991), The Ideal and Reality of the Republic of Letters in the Enlightenment, Science in Context, 4 (2), pp. 367-386. The expansion of the public press and the economic development of the publishing trade also played a role in showing up the contradictions between the code of civility of the Republic of Letters, economic interests, and the concept of useful and trustworthy information that ended in profound changes of the concept of the honnête homme, see GoldGAR (1995), pp. 237-238; PococK, J.G.A. (2002), Clero y comercio: la ilustración conservadora en Inglaterra. In PocOCK, J.G.A., Historia e Ilustración. Doce estudios, Madrid, Marcial Pons, pp. 175-210.

16 See Koerner, L. (1996a), Carl Linnaeus in his time and place. In Jardine, N., SeCORD, J.A. and SPARY, E. (eds.), Cultures of Natural History, Cambridge, Cambridge Univer- 
during the Enlightenment also fostered a new concept of knowledge that focused on error as imprecision, which could therefore be corrected through practice and discipline and which had consequences in the way scientific knowledge was created and communicated: the writing of a scientific text, the way data was collected, and the management of credibility were all subjected to a process of depersonalization, depuration and adjustment, profoundly linked to the emergence and spread of a series of mechanical and/or analytical instruments. ${ }^{17}$

Aware of the connection between a proper symbolic mobilization and the right to claim a possession, as also of the threat posed by the new Republic of Letters' conception of truthfulness and accuracy for the integrity of its empire, the Spanish government realized that for both economic and diplomatic reasons, information had to be produced which met the new requirements for trust. ${ }^{18}$ Great hopes of success in spreading the moral values of science were

sity Press, pp. 145-162; KoERner, L. (1996b), Purposes of Linnaean travel: a preliminary research report. In MiLler, D.Ph. and ReILl, P.H. (eds.), Visions of Empire. Voyages, Botany, and Representations of Nature, Cambridge, Cambridge University Press; CoOPER, A. (2003), The Possibilities of the Land: The Inventory of «Natural Riches» in the Early Modern German Territories, History of Politic Economy, Annual Supplement to vol. 35, pp. 129-153.

17 For the progressive disappearance of the scientist from the scientific text in early experimental sciences, see LICOPPE, Ch. (1996), La formation de la practique scientifique. Le discours de l'expérience en France et en Angleterre (1630-1820), Paris, éds. La Découverte). The Enlightenment period saw a second stage in the search for a scientific language able to avoid subjective bias and to reach the highest degree of consensus in communicating scientific knowledge and social articulation, as analyzed in RiSKIN, J. (2002), Science in the Age of Sensibility. The Sentimental Empiricists of the French Enlightenment, Chicago/London, University of Chicago Press, p. 240ff; and BATES, D. (1996), The Epistemology of Error in Late Enlightenment France, Eighteenth-Century Studies, 29 (3), pp. 307-327. In the meantime, the use of mathematical instruments faced unexpected problems such as the lack of evidence for measurements and the difficulties in making them comparable, as in the case of the geodesic expedition to Peru (LAfuente, A. and MaZuecos, A. (1987), Los caballeros del punto fijo. Ciencia, politica y aventura en la expedición geodésica hispanofrancesa al virreinato del Perú en el siglo XVIII, Barcelona, CSIC/Serbal). The connection between this problem and the notion - which emerged in late 17th century France and was linked to technologies related with calculus and estimation (vs. census) — of precision as a «degree of necessary truth» allowing scientists to erase epistemological differences between precision and mathematical accuracy —RUSNOCK (1995) - was then difficult to see.

18 In 1751, Father Martín Sarmiento, then Cronista de Indias, insisted on noting that foreign taxonomies, maps and natural histories were acting as tools to dispossess the Spanish Empire of its territories and natural wealth (SARMIENTO, M. (1751), Plano para formar una general descripción geográfica de toda la Península y América. In Escritos geográficos, ed. 
enthusiastically placed in the new and expensively acquired equipment, as if both their use and the very idea of precision were easily understandable and unproblematic.

But although precision was mainly linked to mechanical instruments, and to technological mediation, the users' body would prove to play a major (and problematic) role in defining it. Precision was the result of training in the use of instruments, and hence the link between body and precision; it was aimed to produce almost automatically deployed skills. The role of these skills and body-embedded knowledge, and the way they were made either public and/or controllable, was different depending on the network or communities within which they were deployed. This provided different functional approaches to the observer, and hence different ways of making it accountable, with consequences on how precision was understood and assessed. ${ }^{19}$

By the middle of the century, a flow of mathematical and observational instruments entered the Spanish official ranks, and, almost simultaneously, classrooms, newspapers, academies, workshops, and cabinets. Amateurs were invited to mathematics and experimental physics classes at the Jesuit colleges, the Navy had opened new schools to improve the scientific training of midshipmen, the Jesuit Colegio Imperial was paying special attention to surveying, and a new accounting corps had emerged as a consequence of the cadastral works. But while schools and academies were suitable spaces to control

and introduction by Pensado, J.L., Santiago de Compostela, Xunta de Galicia, 1996, p. 89). Gandara's recommendation to impose «one currency, one law, one weight, one measure, one language, and one religion» expresses the extent to which the empire's prosperity was considered dependent on making information exchanges homogeneous, accountable and reliable (GÁndARA, M.A. De LA (1988), Apuntes sobre el bien y el mal de España, ed. and introduction by Macias Delgado, J., Madrid, Instituto de Estudios Fiscales, p. 214; see also SteIN, S.J. and SteIN, B.H. (2000), Silver, Trade, and War. Spain and America in the Making of Early Modern Europe, Baltimore/London, The John Hopkins University Press, pp. 200-230; CAÑIZARES-Esguerra, J. (2001), How to Write the History of the New World. Historiographies, Epistemologies, and Identities in the Eighteenth-Century Atlantic World, Stanford, Stanford University Press, p. 155ss).

19 I use Schickore's definition of functional approach, that is a concrete view of the possibilities and faults of an artefact that is supposed to be able to reach a purpose (SCHICKORE, J. (2002), (Ab)Using the Past for Present Purposes: Exposing Contextual and Trans-Contextual Features of Error, Perspectives on Science, 10 (4), p. 445). In general, I shall refer to the mechanical approach as the state of transparency attained by some elements - e.g. the eyes as transparent medium (vid. SCHICKORE, J. (2001), Ever-Present Impediments: Exploring Instruments and Methods of Microscopy, Perspectives on Science, 9 (2), p. 129) — in the sense that they are supposed to work properly, without interfering in the process of observation. 
the values and practices desired to be spread, the spaces of public opinion would display a number of contradictions.

The popularization of scientific equipment such as microscopes, barometers and thermometers, the increasing amount of information on scientific discussions, technical devices, shops and vendors, science-fiction-like narratives, and do-it-yourself recipes seemed to produce a different kind of precision. Criticism of these works pointed at their lack of seriousness or rigour, but to understand what this meant we must recognize these texts' inner logic. For instance, the recipes of 18th century books of secrets and almanacs were often headed «another one to [do] the same.» This meant that with different materials one could make objects functionally similar, despite a radical material reconstruction. An especially clear case is the secret entitled «a Barometer without quicksilver: ${ }^{20}$ putting a leech on a flask partially filled with water, the animal's position on the bottle would show the degree of humidity in the atmosphere. A link with mechanical barometers was thus created, loosening the definition of the instrument and making it more fluid; ${ }^{21}$ this was the kind of association that it was impossible to sustain within a network devoted to gathering and comparing data, and hence needing sound and stable material definitions. Such reinterpretations and uses of unexpected materials, as well as challenging centralized networks, entailed a disturbing and alternative redefinition of mechanical precision - posing the question of what should be considered a legitimate observation-; but these kinds of recipes also promised to provide valuable experience to the amateur practitioner, making his body suitable for the storage of performative knowledge and expertise. Popular literature thus linked the use of scientific or scientific-like instruments with body knowledge and social authority.

This situation was correlative to an evolving and unstable concept of precision. From 1737 to 1803 the meanings of the word in the Diccionario de

20 GonzÁlez, J. (1760), Nueva mágica experimental permitida: Ramillete o Manojo de selectas flores, tanto arithméticas como physicas, astronómicas, astrológicas, históricas, graciosos juegos, \&c, [...], Madrid, Domingo Fernández de Arrojo, p. 93; SERRANo PALACios, I.J. (1759), El Jardín de Curiosas Questiones, y ramillete de los mejores remedios médicos [...], Madrid, Antonio Muñoz del Valle, p. 32.

21 I borrow the term from LaET, M. DE and Mol, A. (2000), The Zimbabwe Bush Pump: Mechanics of a Fluid Technology, Social Studies of Science, 30 (2), pp. 225-263. It refers to the limits of change, both material and cultural, that an object or actant can bear without losing or changing its identity (see also LAW, J. (2000), Objects, Spaces, Others, published by Center for Science Studies, Lancaster University, UK, at http://www.lancs.ac.uk/fass/sociology/papers/lawobjects-spaces-others.pdf. (consulted on 21-10-2010)) 
Autoridades increased in order to clarify the difference between precision as the suppression of superfluous information in an account, and precision as the result/act of identifying discrete elements, i.e. parts, measures, timing, or positions. The two definitions were not mutually exclusive even if, as Golinski has shown, ${ }^{22}$ the scientific arena had difficulty integrating numbers and quantities into a community that required consensus. Despite this conceptual and social instability, precision was to become a major requirement in order to be a recognised member of the Republic of Letters, to be appointed as a commissioner of the Crown, or to be considered a profitable subject. This means that the urgent task of assessing when a value might be considered accurate, i.e. where the threshold of the degree of required precision should be placed, was distributed among an ample range of communities that created different mechanisms of mutual adjustment between rules and actors. ${ }^{23}$ Users had to face unforeseen challenges related to the practical, political, social and cultural understanding of their task which, forcing them to seek coherent ways of constructing the links between their bodies, their instruments and their inscriptions, contributed towards shaping the value of precision.

\section{ACCOUNTABILITY WITHIN FORMAL NETWORKS}

Most of the instruments acquired by the Spanish Court between 1750 and 1753 went to the Imperial Observatory (1750) at the Jesuit Colegio Imperial (1625), the House of Geography (1752) or the Royal Navy Observatory at Cádiz (1753). They were clearly intended for use in correspondent observation networks and expeditions. Within both kinds of network, observers were to face a series of problems mostly related with reliability, the limits of the instruments, and the hierarchization of the information. Let us examine, firstly, how the Bohemian Jesuit mathematician Johan Wendlingen (17161790) dealt with such problems.

22 Golinski, J. (1995), «The Nicety of Experiment»: Precision of Measurement and Precision of Reasoning in Late Eighteenth-century Chemistry. In WISE, N. (ed.), The Values of Precision, Princeton, Princeton University Press, pp. 72-91.

23 Porter, T. (1992), Quantification and the Accounting Ideal in Science, Social Studies of Science, 22 (4), pp. 633-651, p. 635. For a detailed explanation of how this adjustment works in establishing a degree of precision, see the case of Maxwell and the determination of an absolute value to $V$ - the ratio between electrostatic and electromagnetic unities - in SchAFFER, S. (1995), Accurate Measurement is an English Science. In WISE, N. (ed.), The Values of Precision, Princeton, Princeton University Press, pp. 135-172. 
Wendlingen, a former disciple in Prague of fellow Jesuit Joseph Stepling (1716-1778), was appointed professor of mathematics at the Colegio Imperial of Madrid and director of its re-founded Astronomical Observatory in 1750. He was also Main Cosmographer for the Indies, a position which had gone together with the post of main mathematics professor since the very foundation of the school in 1625. By 1748, having returned to Paris from Russia, the French astronomer Jean Nicolas Delisle (1688-1768) reorganized his European network of observers to prepare for observations of the expected transits of Mercury in 1753 and Venus in 1761, events which would be used to establish a universal astronomical measure. ${ }^{24}$ Wendlingen was one of the few Spanish astronomers to take part in the project, and he began a correspondence with Delisle eagerly. However, when he received from Delisle the astronomical observations of a lunar eclipse by Pierre Bouguer (1698-1758), Pierre-Charles Lemonnier (1715-1799), César-François Cassini de Thury (1714-1784; Cassini III) and Giovanni Domenico Maraldi (1709-1788; Maraldi II), as well as Delisle's own observations, Wendlingen was greatly surprised.

«How is it possible,» he asked the French astronomer, «that all of them having made rigorous observations of the same eclipse and in the same town these observations disagreed so much with each other? [...] being also hard to believe,» he added, «that so big an error [aequivocationem] can be caused by such trained people as I think your observers are. $\gg^{25}$

Wendlingen was an untrained astronomical observer, and his disappointment derived from his discovery of the fact that having proper instruments and following a strict observational protocol did not automatically lead to comparable results. Observations turned out to be more unstable than he had thought. In addition, Wendlingen would soon discover that instruments could even be a source of confusion. Three months later he wrote to Stepling:

I do not want to hide from you what happened to me during one observation. To see the emergence of the first satellite of Jupiter, I arranged two telescopes, one with $16^{\prime}$ focus and the other with $36^{\prime}$ and the difference in aspect was amazing; I say amazing because of the difference in magnitude; with the second, the emer-

24 See Woolf, H. (1959), The Transits of Venus. A Study of Eighteenth Century Science, Princeton, Princeton University Press.

25 Wendlingen to Delisle, Madrid, March 17, 1751. Correspondance de M. Delisle - hereafter $C M D$ - T. XI, n. ${ }^{\circ}$ 95, fol. 1r, Observatoire Paris Meudon, AB 1-6 (in Latin). 
gence of the satellite was observed 2' $30^{\prime \prime}$ earlier than with the first; from which I infer: it is useless, and all work is jeopardized, if, when determining the longitude of a place only the position of the satellites is given, even when accuracy of observation is claimed, and all the features of the telescope used are not also given. ${ }^{26}$

Wendlingen had become aware that in making calculations he could not take for granted the functional features of the instruments, and it is worth noting that he reached this conclusion only because of the diversity of the astronomical equipment at his disposal.

In the same way, when two observers shared the same space, they unveiled new hindrances to accurate calculations, as happened when Wendlingen added the observations of his disciple, Antonio Luis Real y Lombardón, to the correspondence with Delisle. The two men's observations contained some discrepancies, the reasons for which were unclear and caused Delisle to ask several questions about the instruments and filters each had used, on the way the information was given - e.g. Wendlingen omitted seconds but failed to explain that this was because their value was zero- or even on the issue of Lombardón's physical limits: «Was he able to resist the Sun's light without any smoked or coloured glass until the end of the eclipse with the telescope he used? ${ }^{27}$ All this information, as Delisle explicitly recognized, did not improve or demean the observations, but helped to make better use of them. A proper use of any observer's data was linked to profound knowledge both of the model of his instruments, and the observer's movements and habits during the observation. ${ }^{28}$

The need to answer inquiries about any step taken was to put the observers into a situation of self-monitorization, in order to be able to give the due an-

26 Clarissimi Wendlingen ad Clarissimum Stepling, 23 Junii, 1751. In STEPLinG, J. (1782), Litterarum commercium eruditi cum primis argumenti, Wratislaviae, Guil. Theoph. Kornii, Epistola XLIX (in Latin).

27 Delisle to Wendlingen, Paris, October 8, 1754, CMD, T. XIII, n. ${ }^{\circ}$ 70, fol. 1v. ANP, Marine, 2JJ/68 (in French).

28 It was, then, a great task of synchronization, understood as an attempt to establish the essential conditions that allow instruments not to be questioned again and again. But this synchronization is defined by a sort of indiscrimination between what Pickering calls material procedures and instrumental models, that is, the set of practices and actions that take place in the laboratory and the understanding of how the apparatus functions. In principle the former determines the latter, but, as we shall see, it has not always been possible to make a clear distinction between the two functions, since both emerge at the same time. See PICKERING, A. (1989), Living in the Material World: on Realism and Experimental Practice. In Gooding, D., PInch, T. and Schaffer, S. (eds.), The Uses of Experiment. Studies in the Natural Sciences, Cambridge/New York/Melbourne, Cambridge University Press, pp. 275-297. 
swer and to anticipate possible queries. They soon accepted that their activity must be organized to the extent of being completely accountable. Thus, when Wendlingen was asked how he had reached an exceptionally accurate value of the ecliptic ( $23^{\circ} 28^{\prime} 20^{\prime \prime} 30^{\prime \prime \prime}$ in 1754), he answered not by explaining the calculations but by describing his instruments and relating step by step what he did each time he made a measurement: every day, during the two weeks before the solstice, he had verified the three foot astronomic quadrant and its micrometer by Adams, adjusted the pendulum by Elliott to the Sun, and made sure that the quadrant was in the plane of the meridian. When measuring the meridian altitude of the Sun, he had used the upper limb of the quadrant to avoid refraction, since in previous observations he had noticed that its effects became greater the nearer was the Sun to the horizon. Finally, he explained, if there was someone at hand to help him, he also observed the apparent diameter of the Sun. ${ }^{29}$

Wendlingen did not take it as guaranteed that all these movements, described as a protocol, were expected to be made by any other observer. As an individual body, the only one linked to those observations, he had to make it clear that his movements were these and these only every time that he made an observation. By actualizing his handling of the instruments, Wendlingen was able to construct the accuracy of (his) observations and his own reliability as an observer, making it clear that his movements did not affect the accuracy of the instruments, thus easing calculation and eliminating as far as possible any suspicions about his intervention. But he also gave Delisle the opportunity of valuing his performative knowledge and enabled him to make a clear distinction between observation and calculation. In valuing the accuracy of calculations, he had a functional approach to the instruments; but to establish the quality of an observation he used a mechanistic approach to the instruments and a functional approach to the observer, in the sense that he had to show that - like Boyle's air pumps - he had no leak. The reliability, and hence the stability, of the data lay in the quality of the instruments, but also in the stability of a predictable, hence negligible, observer. But there were other possibilities for reaching this stabilization which were important in claiming precision, such as those taking place in the Spanish expeditionary networks at the same time.

The expedition launched to settle the issue of the Hispanic-Portuguese border in the Americas was the greatest instrument ever created in 18th cen-

29 Wendlingen to Delisle, November 20, 1756, CMD, T. XIII n. ${ }^{\circ}$ 179, ANP, Marine, $2 \mathrm{JJ} / 68$ (in Latin). 
tury Spain designed to stabilize an object - South America - and connect it to property rights. The imaginary line established by the Treaty of Tordesillas (1494) had been disregarded both by the Spanish, who colonized the Philippines, and the Portuguese, who expanded their Brazilian possessions inland. The aim of the new Treaty of Limits (1750) was to prevent such annoying mobility by fixing physical and stable points through which the borderline should pass. Expedition members were expected to determine «with the greatest precision possible and without the slightest doubt for the future, the places the line must pass through in those parts that are not named and clearly specified in the above articles.» ${ }^{30}$ Such a statement was quite ambiguous, because the methodology was not clearly determined. There were good reasons for such ambiguity. Spanish authorities referred to the treaty as the «Treaty on the limits of all the American territories of both Sovereigns,» or more familiarly the "Treaty of Exchanges.» But to the Portuguese it was known as the «Treaty on the limits of the Royal Territories and Conquests in America.» The Portuguese, in other words, had a different view of the treaty's purpose. Spain wanted (and needed) an internationally valid document to solve all queries about its dominions, and high European standards of precision were required to leave such issues uncontested. On the other hand, the Portuguese simply needed an agreement that legalized appropriation of American territory. ${ }^{31}$ The required methodologies would be rather different on each side. While the Spaniards needed astronomers and geographers able to handle a language independent of possible local changes - such, for example, as the renaming of a place or geographical feature-, the Portuguese insisted on reaching an agreement about the toponymy.

Moreover, a map, called the Map of the Courts, was attached to the treaty. This map, carried out by the Portuguese and based on the documentation they had collected to prepare the treaty, showed errors aplenty, as both expeditionary teams recognized. But, once signed by the two plenipotentiary ministers, it posed uneasy questions concerning whether it could ever be corrected and for what technical and moral reasons it might be changed. Thus, the first problem to solve was that of assessing its interpretation.

The Spanish commission claimed that, in spite of its errors, the map represented the relative distances between the points of the borderline, as well as

30 Tratado firmado en Madrid a 13 de enero de 1750 para determinar los límites de las Coronas de España y Portugal en Asia y América, 1836, pp. 11-12.

31 Lucena GiRAldo, M. (1993), Laboratorio tropical. La Expedición de Límites al Orinoco 1750-1767, Caracas, Monte Ávila editores/CSIC, pp. 78-79. 
the orientation of the rivers and mountain chains. In any case, the treaty explicitly stated that straight lines must be used as far as possible, and that if there was any doubt about establishing the headwaters of a river, its biggest branch must be chosen. So, for example, if the map showed 35 leagues between the Negro River and another river (unnamed on the map) in a given direction, a river that fitted those requirements must be looked for ${ }^{32}$ In this case, the unnamed river forked into two branches. Thus, in order to support the supposition that the headwaters of the river were in the Montegrande chain, the expedition members needed to train a Jesuit father, Miguel de Soto, to make good measurements with a sounding line in the right season, in order to prove that the branch that led to Montegrande was greater than the other. ${ }^{33}$

To the Portuguese, the map was merely a design that grosso modo represented the figure drawn by the borderline in the field. ${ }^{34}$ They also thought that since the errors on the map were of the order of one degree, the relative distances should not be taken into consideration. ${ }^{35}$ Therefore, if the river arising in the Santa Tecla chain fitted the features of the borderline depicted on the map, this was the one that must be pursued to establish the boundary. ${ }^{36}$ They did not deem it necessary to verify which of the two rivers was the biggest, stating that they had been commissioned to identify the physical limits of a treaty on the basis of analogy, not to map the field. They even sent back to Europe the Jesuit Italian astronomers employed by the crown as a way of stressing that no mathematical precision was needed to accomplish their task. ${ }^{37}$ [Spanish navy

32 See Valdelirios to Sâ e Faria, September 11, 1759 (Archivo Histórico Nacional — hereafter AHN-, Estado, leg. 4798, n. ${ }^{\circ} 75$ ).

33 Father Miguel de Soto to Juan de Echevarria (AHN, Estado, leg. 47982, n. ${ }^{\circ} 233$ ); Juan de Echevarría to Father Miguel de Soto (AHN, Estado, leg. 47982, n. ${ }^{\circ} 234$ ).

34 Sâ e Faria to Valdelirios, April 14, 1759 (AHN, Estado, leg. 4798, n. ${ }^{\circ}$ 69); and also «Suplemento que por ordem do Illmo Exmo Snr. Gomes Freyre de Andrada do Consello de S. M. [...] fez Jose Custodio de Sâ e Faria [...] Anno MDCCLVIII.» Report sent to Valdelirios on March 30, 1759 (AHN, Estado, leg. 4798, nº 81, [s.n. ${ }^{\circ}$, fol. 3r.]).

35 Sâ e Faria to Valdelirios, April 14, 1759 (AHN, Estado, leg. 4798, n. ${ }^{\circ}$ 69); and also «Suplemento que por ordem do Illmo Exmo Snr. Gomes Freyre de Andrada do Consello de S. M. [...] fez Jose Custodio de Sâ e Faria [...] Anno MDCCLVIII». Report sent to Valdelirios on March 30, 1759 (AHN, Estado, leg. 4798, $n^{\circ}$ 81, [s.n. ${ }^{\circ}$, fol. 3r.]). A longer discussion of the map's inaccuracies in Sâ e Faria to Valdelirios, October 11, 1759 (AHN, Estado, leg. 4798, n. ${ }^{\circ}$ 76).

36 This does not mean that the Portuguese did not use any mathematical data in interpreting the map, but in their view, the use of mathematics and observations did not justify any possible alteration of the drawn borderline.

37 Valdelirios to Sâ de Faria, June 23, 1759 (AHN, Estado, leg. 4798, n. ${ }^{\circ}$ 66). 
officers were trained in handling topographical and astronomical instruments to accomplish these tasks.]

The gap between both teams became even clearer when, while taking measurements of the Santa Tecla Mountain, Juan de Echevarría, commissioner of the first Spanish party of the expedition, found an error of 2 leagues $\mathrm{N}-\mathrm{S}$, or six minutes, in the measurements between Santa Tecla and Santa Catalina. This deviation was due to the continuation through the line N-S of the celestial height calculations to determine the latitude. Since the maps of the area where the error was detected had already been signed and delivered to the Portuguese court in 1753, the Spanish team proposed two solutions to rectify the error: firstly, to correct the graduation on subsequent maps by reducing some seconds between Santa Catalina and the fork of the river; and secondly, to add a note to the map explaining it.

José Custodio de Sâ e Faria, lieutenant general for the Portuguese commissioner of the expedition, and Gomez Freire de Andrade, Conde de Bobadela (1733-1763), initially accepted the idea of making the rectification in subsequent maps, but later rejected both proposals. He refused to write a note because it would discredit the map at first glance and would have a bad effect on the image of the expedition, its members, and the kings of the two countries. He also turned down the idea of compensating for the error in the next map to be published, because a private amendment of which the King had no knowledge was a betrayal of the trust he had placed in them. ${ }^{38}$ Bobadela's position contrasts sharply with the Spanish commissioners' view of what constituted a real and accurate world.

From the perspective of the Spanish team, the most sage and expert observer had been subjected to error. ${ }^{39}$ Thus, no authority could offer absolute and unquestionable data, a circumstance that did not discredit the astronomical discipline, but forced it to undertake cartographic and geometric works as a team and to average the results, thereby avoiding or minimizing the contingencies to which any individual practice and measurement was subjected. ${ }^{40}$

38 Sâ e Faria to Valdelirios, July 3, 1759 (AHN, Estado, leg. 4798, n. ${ }^{\circ}$ 67).

39 The sources of it were his eyes, the instrument, weather, or simply that calculations were approximate, «not infallible,» Valdelirios to Sâ e Faria, June 23, 1759 (AHN, Estado, leg. 4798, n. $\left.{ }^{\circ} 66\right)$.

40 This position contrasts starkly with the naive confidence in their instrumental equipment of the members of the Geodesic Expedition to South America of 1734, who seemed to be convinced that it was possible to find an empirical correspondence to a mathematical model. However, in their private papers the expedition members did show some lack of trust in instruments and measurements which were corrected to make them fit expected values 
As it was posed, if the error did not arise from economic or political interest or bias, there was no need to correct the original map but to compensate for it in another part of the work to maintain a reasonable degree of accuracy of the whole. But the only individuals who could locate the error and determine its importance within the general framework of the result were the members of the expert community involved in its production. So the expedition members involved had, first, to separate error originated by non-moral or regrettable practices that altered the map's essence as a diplomatic document from that which stemmed from wanting or misunderstood practices, or instrumental malfunction, but was linked to shared epistemic values; and second, to fulfil the task of maintaining accuracy by adding any data that would have the slightest impact on the final result. Spanish expedition members wanted to make a "good and accurate» map that would be a «certain and true monument» ${ }^{41}$ without increasing costs or time. They had no interest in detecting whether any of the individual bodies or instruments that made up the team worked badly. For them error had, as it were, no source, just a place: the map. By revisiting the map and ensuring that the result reached the standard of precision allowed by the technologies at their disposal, individual selfmonitoring could be avoided. But insomuch as the map was a collective enterprise, self-monitoring reappeared in revisiting the map: its degree of precision and accuracy reflected the team's capacities, know-how and commitment, so that it measured the degree of involvement of the bodies (which explains the reluctance simply to attach a note about the error). A neat and accurate world was one whose representation embedded collective practices established by moral criteria of rigour and took into account the technological limits of precision. Certainly, inner discussion and consensus about the nature of error would also help to avoid any possible interference in establishing who was a reliable member of the team and what kind of work could be claimed to mirror the community's abilities. Even the King lacked the authority to settle such questions.

In any case, the scientific persona, both inside the observatory and in the open air, was immersed in a dense process of construction of the correspondence between his physical dimension and the semiotic definition that quali-

(LAFUENTE and Delgado (1984); LAFUENTE and MAZuECOS (1987)). The main difference between both teams was that in 1750 the problem of distributing the error was not seen as a dramatic solution to the impossibility of calibrating homogeneously the instruments, but as a response to the duty of being useful and productive without renouncing accurate quantification.

41 Valdelirios to Sâ e Faria, April 6, 1759 (AHN, Estado, leg. 4798, n. ${ }^{\circ} 68$ ). 
fied an actor as a suitable element of the network, as a proper observer. ${ }^{42}$ They had to assimilate restrictions and guidelines as part of standard scientific practices; to devote themselves and their work's credibility to the support of a set mechanism of inscription based on values like precision linked to a set of practices - what Daston calls moral economy ${ }^{43}$. But some differences are also worth noting. Wendlingen becomes valuable at the very moment he becomes an accountable observer, a stereotyped individual observer and himself a model. On the other hand, the expedition members become valuable in becoming accountable as a team through the map; in other words, in being able to release inscriptions as maps that would remain unchallenged to the extent that they could successfully claim a reasonable (physical and moral) integrity of their practices and results as a team. Despite these differences, both strategies implied that the observer's capability to do legitimate observations lied in the soundness and strength of the links that could be established between the observer's performance and the mechanical devices employed to do mathematical calculations.

The idea that a neat and accurate result is a product whose rigour depends on the moral management of experts in the field and the distribution of minor variations and inconsistencies was to be important for the Spanish expeditionary project, delaying the publication and sharing of their results. ${ }^{44}$ Mean-

42 A process that anticipates what Schaffer has defined as calibration of the observer. Schaffer, S. (1988), Astronomers Mark Time: Discipline and the Personal Equation, Science in Context, 2 (1), pp. 115-145, p. 119.

43 DASTON, L. (1995), The Moral Economy of Science, Osiris, 10, pp. 3-24.

44 As Dorinda Outram has shown, the expeditionists' way of gathering data reinforced the role of the cabinet scientist insofar as both are understood as different and complementary (inner) spaces (OUTRAM, D. (1996), New spaces in natural history. In JARDINE, N., SECORD, J.A. and SPARY, E. (eds.), Cultures of Natural History, Cambridge, Cambridge University Press, pp. 249-265). Passing from the expedition to the cabinet, knowledge is supposed to lose some of its vivacity and concreteness but to gain in generality and connectivity. During the second half of the 18th century, Spanish expedition members always supposed that the passage from one to another must be carried out by the same person. Thus, every one of the 18th century Spanish botanical (and zoological) expeditions gave rise to its own center of calculation: the so-called botanical offices. There the botanists of the expedition - claiming that only they had the capacity to organize properly the information and discriminate between errors and truth (see SteEle, A.R. (1982), Flores para el Rey. La expedición de Ruiz y Pavón y la Flora del Perú (1777-1788), Madrid, ed. del Serbal, p. 212ff.) - compared, adjusted and stabilized the scientific meaning of any collected specimen. In this way, despite the success in the task of gathering natural history specimens, the trust placed in scientific practices and the new autonomy gained by experts halted the publication of the results, images and materials, 
while, to amateurs and a non-expert audience and readership it became clear that recipes and instructions for use were a key element in understanding and appropriating scientific practices. Underlying complaints suggest that scientific popularisation was playing an ambiguous role in the transmission of those values that were being created in the formal networks.

\section{UNRULED SPACES OF TRAINING}

Public spaces of opinion had been observed in Spain with a mixed feeling of hope and unease since the very emergence of literary gatherings at the end of the 17th century. ${ }^{45}$ In the second half of the 18th century, there was a growing awareness that the accumulation of objects and machines was also a threat to the traditional symbolic and axiological world. Sensibility was being modified, to the great concern of various social sectors. The first signs of this change became apparent in the proliferation of cabinets and collections among the wealthy class. The Church, a good detector of the new attitudes, showed its discomfort by protesting about the alleged confusion that these new objects could produce in the pious soul. ${ }^{46}$ Ecclesiastical authorities were able to see the impact that the wonder and exoticism of such objects might have on the spaces of memory and the social order, by blurring the differences between cabinets and churches. The Church may have had good reason to be on the alert, if comments like the following, to be found in the work of Antonio Romero, author of Piscator de la Farsa, are anything to go by: «Christian reader, (or Moor)/ it is irrelevant to me,/ since in order to be curious/ it is not essential to be Christian.» ${ }^{47}$

which remained out of the public sphere because of the extremely long period needed to embed the knowledge gained «in the field» within the classification.

45 See Zavala, I. (1978), Clandestinidad y libertinaje erudito en los albores del siglo XVIII, Barcelona, Ariel, p. 86.

46 From the pulpit, Father López Cotilla theatrically narrated the amazement of those who, being invited to «these Cabinets, so fashionable, full of Pagan fables, medals, and scenery of false Deities, not finding among them either an Image of Christ or an Effigy of Mary,» asked himself «To whom should I bow to say a prayer?» (LóPEZ CoTILLA, J.A. (S.I.) (1753), Epiphania Mariana ó Manifestación Prodigiosa de María Santissima, Madre de Dios, y nuestra [...], Madrid, Vda. de Manuel Fernández, p. 7v).

47 Romero Martínez, A. (1759), Piscator de la Farsa. Pronóstico, y Diario de quartos de Luna, ajustado al Meridiano de esta Corte, para el año de 1760. Su autor [...], Madrid, Manuel Martín, «Prólogo al lector,» s/n. 
To understand events amidst the expressions of reciprocal scorn between religious power and the new sensibility, the public had to locate itself in a new ground of shared knowledge. This forced one to know several different codes: those of theology, science, and technique. So it is not surprising that there was an increase in the number of scientific entries in dictionaries, and in the number of popular and entertainment books that tackled scientific topics. A feverish taste for almanacs (also called piscatores or pronósticos, most of them with a parodic flavour) seemed to dominate the Madrilenian court at the end of the $1750 \mathrm{~s}$ and beginnings of the $60 \mathrm{~s} .{ }^{48}$ Although this literature was much criticized, scientific-technical knowledge entered the world of commodities via these popular and fragmentary texts written by authors «without name in the Public, without title in the Schools, and without position in the State. ${ }^{49}$ This rather wavering social position, together with economic interests, ${ }^{50}$ forced these new writers to pay special attention to the kind of information demanded and to the reading habits of their potential clients. Brevity, a relative independence from a reformist program or the «correction of errors, $\rangle^{51}$ as well as the promotion of participation as an essential form of entertainment, were the main features of this literary genre.

48 From 1750 to 1800 around 219 pronósticos were published; 132 of them between 1750 and 1767, of which no less than 74 were published for the first time in Madrid (AguILAR PIÑAL, F. (1978), La prensa española en el siglo XVII, diarios, revistas y pronósticos, Madrid, CSIC). From 1767 to 1771 pronósticos, and other popular literature such as romances de ciego, were banned by Royal decree. In general, however, the $60 \mathrm{~s}$ was a golden age for the Spanish press - mainly that of Madrid, which then produced more than half of the periodic publications of the century - since 45 new newspapers were then published, whereas up until 1760 there had never been more than an average of one new newspaper per year (SÁNCHEZ ARANDA, J.J. (1990), Una aproximación informática a la prensa del siglo XVIII como instrumento de difusión cultural, Estudios de Historia Social. Special issue Periodismo e Ilustración, 52-53, pp. 469-476, p. 471).

49 Martínez SalafrancA, J. (1736), Memorias eruditas para la crítica de artes y ciencias, Madrid, Juan de Zúñiga, p. 2 v.

50 See Zavala, I. (1987), Lecturas y lectores del discurso narrativo dieciochesco, Amsterdam, Rodopi, pp. 64-65; Álvarez BARRIENTOS, J. (1990), El periodista en la España del siglo XVIII, Estudios de Historia Social. Special issue Periodismo e Ilustración, 52-53, p. 30-31.

51 This does not mean there was a total absence of reflection on the moral role played by popularization. For instance, Gerónimo Audixe de la Fuente wrote in the introduction to his Pronóstico: «Any rational man deserves reproach for not having at least a general idea of the order, division, measurements and distribution of this House he inhabits [...]» (AUDIXE DE LA Fuente, J. (1759), El Piscator de Guadalupe para el año de 1760. Medida de la Tierra y división de sus climas [...], Madrid, Viuda de Manuel Fernández, pp. 1-2). But in this case, what is regretted is lack of curiosity, not errors of knowledge. 
In general, three types of entertainment, often mixed together in the same pronóstico, were placed on offer: discussion of proposed issues, fables organised around scientific or pseudo-scientific data, and experiments or so-called experiences. Experiences focused mainly on technical and experimental knowledge, and depending on the author's background, could include things like medical prescriptions and practices or mathematical tricks. The sources of the piscatores were usually the so-called «books of secrets.» It was from the virtuosos and polymaths of the previous century, and classics like Hero of Alexandria, or Albertus Magnus, that the 18th century piscatores took their model. Of course, new references were included, some as foreseeable and essential as Caspar Schott (1608-1666), others with a stronger local flavour, such as Manuel Ramírez de Carrión (fl. 1629), Gerónimo Cortés (fl. 1615), Vicente Tosca (1651-1723), or the physician Martín Martínez (1684-1734).

Only occasionally did the authors of these new secrets offer a more or less appropriate explanation of the effects produced by the experiments they proposed. ${ }^{52}$ Explaining how a scientific instrument works, they argued, was the task of physicists, ${ }^{53}$ whereas theirs was to explain how to make, identify or use one. One major problem in these texts was therefore to search for a way to convince readers of their truthfulness and utility. Books of secrets had sought to do this by listing the authorities that endorsed them. But this new literature tended to highlight the author's contribution, as he explained that his (unnamed) sources had been chosen from among «the most famous ancient and modern authors,» but that it had also been necessary «sometimes to ask meritorious artificers, to make several experiments, to commit on the opinion of scholars, $\gg$ thus creating the impression of an increasing distance from bookish knowledge, and promoting the idea that what was transmitted was part of the author's own experience.

52 E.g., in 1747 Joseph Patricio Moraleja y Navarro published his Piscator seri-jocoso [...], a work whose content is very close to that of the English books of secrets of the second half of the 17th century, as described in EAMON, W. (1994), Science and the Secrets of Nature. Books of Secrets in Medieval and Early Modern Culture, Princeton, Princeton University Press, pp. 308-311. The trick entitled «To put a sheet of paper into water without wetting it,» a simple case of difference of density, is explained in these terms: "the cause is the air that enters into the glass when it is put straight in the bucket full of water.» (MORALEJA Y NAVARRO, J.P. (1747), Piscator seri-jocoso, intitulado el nacimiento del año nuevo de 1748 [...] con exquisitos Quentos para reir; un Entremés famoso; aprobados naturales Secretos; y quarenta curiosas Enigmas, o Quisicosas [...], Madrid, s.n., p. 54).

53 GONZÁLEZ (1760), p. 113. 
Some explicit and implicit rules were created. A major clue in verifying whether a recipe was functional or not was the absence of variation in its formulation. If a secret had been «approved by experience,» then one must not change «the very same shape and words that their authors used to write them; $\gg{ }^{54}$ conversely, if one found the same experience in several authors, "and each one tells of it in a different way, one can deduce that the effect is quite doubtful.» ${ }^{55}$ Modifications in the text implied variations in the protocol of the production of the experiment, indicating that it was not easily replicable.

Little by little, such interpretations ceased to be sufficient. The reader as experimenter came to accept greater responsibility for the success or failure of his practices. Warnings were clear: often it was

not enough to achieve success to follow literally the formulas here prescribed, because in spite of their experienced effectiveness, often a bad choice of ingredients, some defect in the recipients, a short or excessive amount of fire, the doer's lack of practice, which is the main thing; or finally a multitude of apparently slight or unnoticed accidents, can make all the work fruitless. ${ }^{56}$

To attain success, «the only remedy is to repeat the tests with perseverance, redoubling observance of the rules given, and thus the aim will be finally reached, as experience has already shown to thousands. $\rangle^{57}$ Although attention was paid to the quality of the material equipment, practice and repetition were claimed to be the core of expertise and understanding in an epistemological context in which theoretical knowledge was put to one side: no instrumental models were required. Books of secrets taught readers how to do, they condensed manual work. When authors discussed the understanding of results, they referred to the understanding of the process of production of results. ${ }^{58}$ The results promised by the recipes attest the existence of a community of practitioners that knew how to produce them.

54 MonTón, B. (1734), Secretos de artes liberales y mecánicas: recopilados y traducidos de varios y selectos authores que tratan de phisica, pintura, arquitectura, óptica, chimica, doradura, y charoles, con otras varias curiosidades ingeniosas [...], Madrid, Antonio Marín, prologue, $\mathrm{s} / \mathrm{n}$.

55 GONZÁlEZ (1760), p. 83.

56 Secretos raros de artes y oficios (1806), $3^{\mathrm{a}}$ ed., Madrid, Villalpando, vol. VI, prologue, s/n.

57 Secretos raros de artes y oficios (1806). Emphasis is mine.

58 As the anonymous compiler of the Secretos raros claimed: «the crowd [...] has the right to be instructed by results that it understands and by immediate advantages that it can touch.» (1806, vol. 4: VI). 
Repetition in this context has little in common with the epistemological importance of repetition claimed by philosophers. Andrés Piquer y Arrufat (1711-1772), doctor and professor at the University of Valencia and an eclectic philosopher, besides advising on the need to avoid imagination and prejudice while carrying out an experiment or observation, claimed that perception, due to the intrinsic instability, variety and complexity of the human body, could lead one to attribute to the object things that are only in ourselves; ${ }^{59}$ repetition is then a methodological tool «to assure (oneself) many times of the way and circumstances on an effect whose cause is sought.. ${ }^{60}$ What was stressed was the difference between a possibility and a probability.

The effects of repetition on training are different, as is shown in the works of Pedro Alonso de Salanova y Guilarte, self-taught journalist and amateur and later professor of Geography and Calendar at the Royal Astronomical Observatory and lieutenant of the State Corps of Engineer Cosmographers (1796). Salanova entered the public arena in 1778 with a paper, Sueño astronómico en el Gabinete de Urania, which while assuming most of the literary features of pronósticos, paid great attention to the quality of astronomic instruments in order to establish differences between a «rigorous astronomic way» of making observations, and a «mechanical simple» one. The names of Senex, Adams, Short, Dollond and Harrison were inserted in the description of the muse of astronomy's cabinet. The information it contained about the construction of a parallactic machine seems to have been taken (almost verbatim) from another paper, Discurso sobre el próximo tránsito del planeta Ve$n u s$, written in 1761 by the military engineer Antonio de Gilleman, one of the witnesses at Wendlingen and Lombardón's observation of the transit of Mercury in 1753. Gilleman's aim in giving such instructions had been «to teach how to observe the transit comfortably, not as Astronomers,» which would imply disposing of expensive instruments, but as «curious spectators.» ${ }^{61}$ Salanova, by contrast, seems to introduce the difference between rigorous and simple practice in the use of instruments to support a more integrative view of scientific practice. His subsequent publication, Disertación fisica sobre la formación [...] del meteoro llamado Granizo (1782), a paper on the nature and microscopic observation of hailstones, ends with the following statement:

59 PIQUer (1745), pp. 10-14.

60 PiQuer (1745), p. 16.

61 Gilleman, A. de (1761), Discurso sobre el próximo tránsito del planeta Venus debaxo del Sol el día seis de junio de este presente año de 1761, y modo fácil de observarlo por cualquier curioso, Madrid, Francisco Xavier García, p. 6. 
«All these characteristics of the hailstone of 26th July of this year have been observed by my diligent survey and care; although it is possible that others may have observed in it other properties, these would never be very different.» ${ }^{62}$ Repetition, not by oneself, but by others, would help to settle a suitable degree of precision, erasing the differences between one's results and those of others. The new cultural trend opened up by popular literature was forging an alternative understanding of the dynamics of the production of knowledge. Based on the convergence of a community of doers - whose virtual presence reinforced the epistemological status of the body - the result seems to be the exact opposite of team work. In the next part of the paper, I shall analyze the controversy that arose between Salanova and the engineer Gilleman in order to explore how informal networks constructed their authority around the practices and abilities that credited their expertise and how this affected their understanding of a hardcore scientific value like precision.

\section{«DEGREES OF PRECISION» AND VALUABLE DEXTERITIES}

In 1788, Antonio de Gilleman, then Colonel of Engineers, gave an address to the Royal Academy of History on the uses of the barometer, as well as presenting a barometer made by himself according to the indications provided by De Luc in his Recherches sur les modifications de l'atmosphère (1772). This new and more perfect instrument, still yet to be mentioned in the most recent works of either Mr. Sigaud de la Fond or Father Cotte, ${ }^{63}$ would serve «as a model to fix with all confidence those that curious people try to set to work in their cabinets either to their own satisfaction, or to enrich meteorology with legitimate and useful observation.» ${ }^{64}$ Modern physics was, he claims, «based on demonstrable experiences» that must be carried out «with scrupulous intelligence and shrewdness» in order to prevent useless and harmful results that could led to many errors. ${ }^{65}$ To keep some control over the useful information that amateur observers could generate, standard mecha-

62 Salanova y Guilarte, P.A. DE (1782), Disertación fisica sobre la formación, tamaño, pesos, figura, color, causas y efectos de el meteoro llamado Granizo [...], Madrid, Imprenta de Miguel Escribano, p. 42.

63 Gilleman, A. De (1788), Discurso sobre el uso y utilidades del Barómetro leído en la Academia el 13 de junio de 1788, Real Academia de la Historia, Mss 9/5947, 211-219 fol., fol. $214 \mathrm{v}$.

64 Gilleman (1788), fol. 215r.

65 Gilleman (1788), fol. 212r. 
nisms such as his barometer had to be established. This was the only way to avoid «ridiculous and detrimental [observations] such as those published every day in this Court, not only carried out with imperfect instruments, but even using false and consequently absolutely useless scales.»166

The accusing forefinger pointed at the newspaper Diario curioso, erudito, económico y comercial - from this year on, Diario de Madrid - whose editor of scientific news was then Salanova. The two men had held private correspondence on the importance of instruments since September 1786. In these letters Gilleman had instructed the Diario's editors (so-called diaristas) to identify excellent instruments and make observations with them which could be used for scientific meteorological purposes. This was used in the following year, when Gilleman published a long letter in the Correo de Madrid numbers 71-74 to correct the calculations of the Carmelite Fray Miguel de Hualde for the dating of Easter, in which the diaristas were also accused of spreading absurd astronomical calculations. These errors, Gilleman wrote, were caused by those who merely copied and reduced calculations «without the due care and calm, and without a deep knowledge and highest practice in every science. ${ }^{67}$ The conviction that the diaristas were not following his instructions had finally triggered a public discussion.

Most of the errors reported by Gilleman pointed at a careless astronomical language that led him to deride journalists, ${ }^{68}$ but his remarks, he claimed, were not made in a satirical spirit, «but to exhort to work with greater exactitude and fidelity when information goes public to avoid the awful embarrassment that ultramontane [i.e. foreign] contempt causes.» ${ }^{69}$ This embarrassment was particularly acute for the «authoritative corps trained in every mathematical science» — such as military engineers and navy officials - who could not «remain silent about the amount of errors published [...] in [their] faces. $\gg{ }^{70}$ Gilleman made it clear that he was playing the role of spokesman of

66 Gilleman (1788), fol. 215r.

67 Gilleman, A. De (1787a), Carta relativa al cómputo eclesiástico, Correo de Madrid, July 4,1787, n. $^{\circ} 74,313-316$, p. 314.

68 For instance, Gilleman says that in the Diario issues of January 13, February 11, and March it had been announced, «that in those days, the Moon would not rise or culminate, i.e. cross through our meridian, nor set.» He wrote maliciously "Where will our satellite be these 24 hours?» (GILLEMAN (1787a), p. 314).

69 GiLleman (1787a), p.314.

70 Gilleman (1787b), Carta del Ingeniero en Jefe D. Antonio de Gilleman sobre las pretendidas satisfacciones de los Diaristas á sus fundados reparos publicados en el $\mathrm{n} .^{\mathrm{o}} 74$ del correo de Madrid, Correo de Madrid, Correo Extraordinario, September 17, 1787, no. 96, 425-430, p. 430. 
that «authoritative corps,» but his criticisms were regarded by the journalists as merely whimsical remarks, as they argued that some of the errors he reported were well-known mistakes «that can be ignored, not being a matter of great consideration. $\rangle^{71}$ Journalists' apparent indifference to precise language was ominous for the sensitivity of true astronomers. Gilleman's letters suggest that the opening of public spaces of opinion to amateurs who disregarded the moral economy of the trained corps jeopardized national dignity, specific astronomical language, precision and its social value. As he saw it, the most important section of the Diario was its second page, where astronomical and meteorological information was given. His opinion was clearly backed by officialdom, since his second reply was published by orden superior, turning a personal dispute into a state affair.

Salanova for his part spoke up on behalf of the literatos, members of the Republic of Letters, and he insisted in this point. He disagreed with Gilleman's opinion about the second page, which was «far from public sentiment.» The first page, devoted to historical, economic and agricultural reports, was most commonly considered the main part of the Diario, its usefulness being «durable and permanent» whereas that of the second was «ephemeral.» Salanova's surprise emerges from the lack of evidence of the accumulative nature and demonstrative value attributed to astronomic and meteorological calculations. $^{72}$ Their fungible, ephemeral nature seemed unsuitable to the making of a sequential, stable text or the metonymic representation of the qualitative work of a man. It was this view of the ephemeral nature of quantifications that Salanova would use to contest Gilleman's accusation about his lack of knowledge and misuse of meteorological instruments..$^{73}$

To show that he was not inferior to the engineer, Salanova argued that he had also written an essay on meteorology - out of his «brain and practice»«lengthy enough, with several scales, and with many very exact figures, delineated and drawn by my pen and hand.»> ${ }^{74}$ By means of these figures and scales he had «given proof and satisfied before the Public and my friends, the

71 Quoted in GiLleman (1787b), p. 427.

72 As Horacio Capel observes, ordinary people were quite disconcerted by the differences in the information given in almanacs and ephemerides, since for them there was no obvious difference between astrology and the new science (CAPEL, H. (1999), Medicina y clima en la España del siglo XVIII, Revista de Geografia, 32-33, pp. 79-105, p. 87).

73 GiLleman (1787b), p. 425.

74 Salanova y Guilarte, P.A. De (1787), Respuesta que D. Pedro Alonso de Salanova $y$ Guilarte hace a la carta del Sr. D. Antonio de Gilleman, coronel de ingenieros, inserta en el Correo de Madrid al n. ${ }^{\circ} 96$ del día 17 de septiembre de este año, s.l., s.n., p. 4. 
remarkable dexterity I have acquired in the handling of mathematical instruments. $\rangle^{75}$ Salanova recalled as witnesses of his dexterity all the

«handwritten pages and title pages I have written to complete cropped books that are now running in Madrid» and also, «the infinite number of drawings and engravings on Geometry, Architecture, Geography, Music and other species».

If the text pages had the merit of being written in different styles (Round hand, Gothic, Italic, Greek, Arabian) the figures had been so minutely copied that they could replace the original pages. All these inscriptions, maps, engravings and manuscripts - both those that reached public spaces and those piled up in the author's home, but accessible to his friends and interested people - had been praised for their delicateness and neatness, and some of them even "seem to have been engraved with a burin. $\rangle^{76}$ But there were other proofs of his skills: human witnesses could testify that he used complex machines - pneumatic and electric ones, telescopes, microscopes, micrometers, anemoscopes, prisms, globes and celestial spheres - and that he had even made a Copernican sphere with «all the movements of the primary and secondary planets. $)^{77}$ Finally, Salanova wrote that he did «not need to study Nicholas Bion's works to learn new things, I know them so well that I have almost forgotten them,» claiming in this way a physical internalization of information.

The accurate drawing of copies used as evidence of one's ability to handle instruments might be considered unstable evidence of scientific knowledge. As Barbara M. Stafford has noted, «faultless hand to eye coordination was a capacity shared by the acrobatic charlatan and sublime artistic genius. $\rangle^{78}$ But by stressing the fact that he was able to make excellent copies, and even to imitate the trace of a burin, Salanova expected to find his place in the realm of objectivity. As copies or simulacra images, his drawings were only secondarily designed to spread data; they mainly talk about the doer. Salanova consistently used them as proofs of his reliability, of his ability to add nothing of his own to results. If the accuracy of his drawing was publicly recognized, and hence the mechanistic-like nature of the register sanctioned, the func-

\footnotetext{
75 Salanova y Guilarte (1787), p. 4.

76 Salanova y Guilarte (1787), p. 5.

77 SALANOVA Y GUILARTE (1787), p. 13.

78 StafFord, B.M. (1994), Artful Science. Enlightenment Entertainment and the Eclipse of Visual Education, Cambridge-Ma./London, The MIT Press, p. 85.
} 
tional approach, any further test of the observer's quality, became unnecessary. Uncontested public drawings would prevent the observer himself from being contested.

Instruments had, of course, a place in shaping the value of precision. As I said above, Salanova made a distinction between the «mechanical and simple» and the «rigorous astronomical» ways of making observations. He described as «mechanical and simple» those observations which, due to the simplicity of the instrument - i.e. their accessibility, material heterogeneity and fluidity - did not require great attention or effort on the part of the observer. Rigorous observations required expensive and bulky instruments, and also practice in handling them. In this case, however, once the proper instrument maker is identified and one of his devices acquired, the observer need not concern himself about it. In this sense, for Salanova a functional view of his Short telescope was not a possibility. Thus, it is that he interprets any remark on calculations as a functional view of the observer. But much the same could be said when dealing with thermometers, more accessible instruments whose maker - as in the case of Salanova - one could not be always be sure of.

If bodies could be trained to a great degree of perfection, instruments could not. The sensitivity of the instruments depended on the sensitivity and sensibility of the instrument-maker, but their construction had so many variables that «a good instrument maker could hardly make two identical [thermometers]. $\gg{ }^{79}$ So instead of claiming to have an excellent one, rather the simultaneous use of several (between four and six) of similar quality -i.e. «made under the same rules, measurements and precautions» by the same craftsman and carrying both the Reaumur and the Fahrenheit scales - arranged in the same room at the same height and distance between them should be preferred. Salanova's preference for average was not linked to a deep knowledge of the instrumental model or a deep understanding of the particular errors of his instruments. On the contrary, the practice of averaging disengaged him from an understanding of the instrumental model, which Gilleman thought was essential in a good observer. Neither was average to him the «true and sure value of the temperature of the air.» Such a value was impossible to attain because of the intrinsic imperfection and incomparability of instruments. But averaging provided a "physical certainty» that possible errors had been minimized. It is this distrust in the accuracy of instruments (when it is possible to gather several in the same place), and the search for a reasonable degree of precision that characterized the "conscious physicist

79 Salanova (1787), p. 12. 
who wants not to stray too much from truth; given that one can never reach it totally. $\rangle^{80}$

Besides the physical (objective) certainty involved in taking measurements with instruments, Salanova believed that once the observer submitted his works to the Republic of Letters, the «conscious physicist» could begin to evaluate the degree of precision required in each case and give approximate results without probable error. Thus, when he explains why he does not use the value of $23^{\prime} 30^{\prime \prime}$ supposedly calculated by Wendlingen as the proper difference between the meridians of Paris and Madrid, instead of the old 24' 18" used by Lalande, he ends by stating: "without doubt all these such insignificant differences do not have much to say; even I, to rid myself of a debatable fraction of seconds, have taken [...] the number 24, the most common opinion, and neither Gilleman nor Lalande will be able to prove that I make any appreciable error.» ${ }^{81}$ An economy of calculus by approximation disengaged him from the rhetoric of the progressive perfection of instruments, which would have forced him to use the latest results. He was not interested in downgrading accuracy, but in reaching a consensus: "Let all of us agree on the practical truth of each one's experience. $\rangle^{82} \mathrm{His}$ was an integrative view of mathematical certainty that would take into account interacting agents and concrete purposes. ${ }^{83}$ In this framework subjective certainties mattered, as far as they were implied in the selection, based on experience, among a set of verisimilar values and/or the identification of suitable ranges of precision for concrete events. This capacity was pivotal to provide feedback to support a changing, wavering but stable and widely spread quantifying account of the world.

\section{CONCLUSION}

Salanova's approach to truth, body knowledge, dexterity as evidence, and instruments seems to be quite problematic in a political and cultural context

80 Salanova (1787), pp. 17-18.

81 SAlanOVA (1787), pp. 6-7. Among the reasons for the rejection was Lalande's slowness in correcting the measurement. He did not do it in his Exposition du Calcule Astronomique (1762), making the journalist think that astronomers had little respect for Wendlingen as an observer. In addition, he claimed that it was the measurement of a German astronomer, as if suspicions of national partiality or lack of local understanding could be projected onto those $233^{\prime} 30^{\prime \prime}$.

82 SALANOVA (1787), pp. 6-7, p. 16.

83 RISKIN (2002), p. 92. 
where the moral economy of precision was expected to play a major role in social reorganization and economic development. The order to ban his response - with which this paper opened - is clear evidence of this. However, Gilleman's understanding of Meteorology as a science that would only increase in proportion to «the quantity of observations legitimately made with equally perfect instruments, [and] communicated to one another in order to form a collection of them and draw consequences from their combinations» ${ }^{84}$ was not radically challenged by Salanova's approach except in one point: the legitimacy of observations did not lie in the perfection of instruments. To some extent this conviction had been shared by the director of the Madrid Academy of Medicine, doctor Francisco de Navarrete, in the first systematic collection of meteorological observations made at the Spanish Court in the 1730s. But Salanova's epistemic culture represents something else, and involved different conclusions about the impossibility of mathematical exactness.

In the three cases analyzed, different processes of distributing accuracy, different economies of precision, were deployed. All of them had to deal with three main issues: defining the ways and processes by which both precision and accuracy could be attained; considering which features of the environment machines and/or behaviour must adapt to in order to attain accuracy, i.e. which aspects of complexity were to be implemented; and deciding which sources of uncertainty and error were to be identified. The choice of one of these systems depended on the structure of the network or the community involved, because actors extracted their conception of accuracy and designed or adjusted their practices from the way they shared their results.

In the case of Wendlingen, we are faced with a negative approach to the observer, who at all events has to show his functional integrity during the observation process in order to guarantee reaching the expected level of accuracy made possible by the instruments. The American expeditions deployed the opposite strategy: the activity of observers was visualized in the final result as a distillation of measurement, observation and assessment practices, and it was supposed that this embedding guaranteed an expected level of accuracy. Their main difference from Salanova is that he disengaged the value as observer from concrete observations. The observer is constructed not during or after the observation, but before. Thus, the expected level of accuracy is relocated.

Both to Wendlingen and the expedition team, accuracy had to be acquired by perfecting the system integrated by the observer and the instrument. This system was the source of error and uncertainty in searching for a result based

84 Gilleman (1788), fol. 215v. 
on optimality. In Salanova's view, bodies could be liberated from uncertainty. For this reason, in comparison with the other two cases, he pays less attention to the process of observation and to the set of practices required to maintain the equilibrium of the observer-instrument system. Instead, he paid greater attention to the question of how the community could identify satisfactory performers. Salanova was interested in making it clear that proper dexterity, linked to performative and working knowledge, might be publicly displayed by using the results of his skill as evidence. It was the level of dexterity that guaranteed that a proper level of accuracy could be reached. However, and contrary to the artisan tradition of the 16th century, ${ }^{85}$ he did not make the value of his dexterity depend on reference to nature. His was a vindication of the autonomous value of the technological knowledge of the user. This kind of knowledge, displayed by exhibiting repeated success in the result of handling mathematical instruments, makes him different from the curious people to whom Gilleman addresses his barometer. These people were expected to provide results without gaining authority, hence without giving any feedback to the community or an evaluative response based on their experience.

Salanova's drawings served to make him equal with other potential observers skilful enough to undertake reliable observations, but they also strengthened certainty of the goodness of his future or possible observations - this is why Salanova pays so much attention to the small number of public images, observations, etc. made by Gilleman - and disengaged him from the observer-instrument system. (For this reason, Salanova does not describe the protocol for making a meteorological observation as a depiction of a personal observation in order to make self-monitoring clear, as Wendlingen does. He uses it as an abstract general rule to use thermometers.) For their part, instruments maintained the physical, causal link with the environment provided by their mechanical organization. But the degree of certainty of such a link (i.e. in the case of thermometers, the certainty that an ascent or descent in the column is equivalent to a change of temperature in the air) is considered independently from the degree of certainty about the quantification of this change. In fact, as Salanova notes, scales as well as accuracy are artificial, they depend on the symbolic system chosen, and they suppose a new factor of complexity and uncertainty (accuracy is a question of degree, not a goal.) In an intrinsically uncertain world (at least from a mathematical or quantitative point of view), his position means that the observer, disconnected from the

85 Smith, P.H. (2004), The Body of the Artisan. Art and Experience in the Scientific Revolution, Chicago/London, The University of Chicago Press, pp. 96-99. 
production of physical certainty (only provided by instruments), could instead provide, by virtue of his experience a suitable interface to test mathematical needs. The way body knowledge (hence performative capability) is assessed breaks the link between instruments, registers and observers that objective precision requires. Once the body is liberated and physical certainty delimited, uncertainty remains as a space for consensus, and experience takes the place of accuracy, because it is experience that provides the organizational key to simulation. Experience gives an answer to the question about the moment at which the limits of computation forced the process of making a decision to maintain a satisfying degree of effort and profit. This question could be posed simply because in the community to which Salanova belonged performance was evaluated independently from the standard protocols of quantification. Within these communities, and contrary to the process of production of mechanical objectivity, machines were not the main source to establish the intensity of the causal connection between data and the world, but a subjective certainty. The kind of precision thus produced was not mobilizable.

Vindication of the subjective evaluation of the degree of precision on the basis both of experience and physical certainty reinforces the ephemeral and strongly situated nature of astronomical and meteorological observation. In this sense, there was little difference between the journalist's approach and that of the expedition members. It might be said that Salanova failed to understand the sequential nature of the quantitative reconstruction of meteorological regularities; but clearly he was able to produce satisfactory (i.e. adjusted to use) accurate results. However, what seems to be the Achilles' heel of his highly integrative approach to measurement is the lack of a mathematical or representational framework of subjective certainty (like, for example, a Bayesian approach.) He lacked, in other words, a mechanism that would serve to make subjective certainty scalable and allow him to make general statements and create models.

Salanova's approach to accuracy was probably seen by the Spanish scientific and political authorities as close to the guilds' old-fashioned methods of problem solving. At the time, leading Spanish engineers were reflecting about models, considering the features they must have and show in order to guarantee the production of working large-scale machines. Proportions and materials were found to be the most important information to provide in order to avoid approximation, opinion, or expertise-based changes. A community of informal experts (not integrated in the dynamic of surveillance or control of the instrument-observer system) able to gain technological and scientific stability on the basis of a flexible, satisfactory (rejecting improbable or unnecessary 
effort and/or results) but oscillating mathematical account of the world had no place in a world where the mobilization of knowledge and technology was a major strategy for the attainment of geopolitical, social and cultural equilibrium and homogenisation.

Fecha de recepción: 26 de enero de 2009

Fecha de aceptación: 1 de junio de 2010 